\title{
Perancangan Sistem Informasi Akademik Berbasis Website Pada SMK Bina Medika Jakarta
}

\author{
Taufik Rahman1, Ananda Bagus Pramastya2, Hafis Nurdin3, Sumarna4 \\ 1,2,3Program Studi Sistem Informasi, Universitas Bina Sarana Informatika \\ JL. Kamal Raya No. 18, Cengkareng Barat, 11730, Cengkareng, Jakarta Barat \\ 2Program Studi Teknik Informatika, Sekolah Tinggi Manajemen Informatika dan Komputer Nusa Mandiri Jl. \\ Jatiwaringin Raya No.18,17411, Indonesia \\ taufik@bsi.ac.idi, anandaba2208@nusamandiri.ac.id2, hafis.nnr@nusamandiri.ac.id3, \\ sumarna@nusamandiri.ac.id4
}

\begin{abstract}
A technology creation starts from the world of education, then the world of education should implement a technology-oriented information system, but in SMK Bina Medika every school academic system procedure is done manually, student data processing, absenteeism, student data search related to academics still must be open the archive sheets in the student information value section, there is no integrated data storage media because student data storage, teacher data, grade data, class data and class schedules that are done now are still using an offline application without you a database, so the problem in SMK Bina Medika, thus slowing down performance in presenting information quickly and precisely. This research aims to design a web-based academic information system. The research method used in this study is the System Development Life Cycle (SDLC) method. The design system in making academic websites uses some software namely Sublime Taxt, Xamp which is a combination of Apache Web Server, PHP, MySQL. Designing an academic information system to facilitate students, teachers and the Bina Medika Vocational High School (SMK) which was previously not available, student data, teacher data and the school is still separate so as to find out full information for quite a long time, with its website-based information system online is expected to make it easier for students, teachers and the Bina Medika Vocational High School (SMK), so that it can be more effective and efficient.
\end{abstract}

Abstrak- Sebuah penciptaan teknologi bermula dari dunia pendidikan, maka dunia pendidikan sepatutnya menerapkan sebuah sistem informasi yang berorientasi teknologi, akan tetapi pada SMK Bina Medika setiap prosedur sistem akademik sekolah dilakukan secara manual, pengolahan data kesiswaan, absensi, pencarian data siswa yang berhubungan dengan akademik masih harus membuka lembaran-lembaran arsip di bagian kesiswaan informasi nilai, belum adanya media penyimpanan data yang terintegrasi karena penyimpanan data siswa, data guru, data nilai, data kelas dan jadwal pelajaran yang dilakukan saat ini masih menggunakan aplikasi offline tanpa anda sebuah database, demikian permasalahan pada SMK Bina Medika, sehingga memperlambat kinerja dalam menyajikan informasi secara cepat dan tepat. Penelitian ini bertujuan merancang sistem informasi akademik berbasis web. Metode penelitian yang digunakan dalam penelitian ini adalah metode System Development Life Cycle (SDLC). Sistem perancangan dalam pembuatan website akademik menggunakan beberapa software yakni Sublime Taxt, Xamp yang merupakan gabungan dari Apache Web Server, PHP, MySQL. Perancangan sistem informasi akademik untuk mempermudah siswa, guru dan pihak Sekolah Menengah Kejuruan (SMK) Bina Medika yang sebelumnya belum tersedia, data siswa, data guru dan pihak sekolah masih terpisah sehingga untuk mengetahui informasi lengkap cukup lama, dengan ada nya sistem informasi berbasis website yang online diharapkan dapat mempermudah siswa, guru dan pihak Sekolah Menengah Kejuruan (SMK) Bina Medika, sehingga dapat lebih efektif dan efisien.

Keywords - Sistem, Informasi, Akademik, Website, Perancangan.

\section{Pendahuluan}

Kemajuan teknologi yang secara terus menerus berkembang dengan pesat ini, diawali atau didasari dari dunia pendidikan yang memberikan pengetahuan, tuntunan dan praktek bagaimana menciptakan teknologi yang uptodate. Oleh karena sebuah penciptaan teknologi bermula dari dunia pendidikan, maka dunia pendidikan sepatutnya menerapkan sebuah sistem informasi yang berorientasi teknologi.

Namun pemanfaatan teknologi informasi ini belum dimanfaatkan secara selektif pada SMK Bina Medika Jakarta karena pada saat ini hampir pada setiap prosedur sistem akademik sekolah dilakukan secara manual. Saat ini pengolahan data kesiswaan, pengolahan informasi nilai, pengolahan informasi absensi dan kegiatan belajar mengajar sebagian besar belum berjalan efektif dan efisien. Pencarian data-data sistwa yang berhubungan dengan akademik masih harus membuka lembaranlembaran arsip di bagian kesiswaan, sehingga memperlambat kinerja dalam menyajikan informasi secara cepat dan tepat. Permasalahan pada SMK Bina Medika Jakarta adalah belum adanya media penyimpanan data yang terintegrasi sehingga kurang efektif dan efisien karena penyimpanan data siswa, data guru, data nilai, data kelas dan jadwal pelajaran yang dilakukan saat ini masih menggunakan aplikasi offline tanpa anda sebuah database. Atas dasar ini, 
muncul ide untuk melakukan sebuah penelitian dengan konsep pemrograman terstruktur dalam aspek dunia pendidikan, yang mana untuk objek yang difokuskan tak lain adalah sebuah instansi pendidikan seperti sekolah. Adapun sekolah yang dispesifikasikan dan dijadikan sebagai wadah dan ruang lingkup untuk penelitian yaitu, SMK Bina Medika.

Sistem informasi akademik merupakan sistem informasi untuk menangani pengelolaan dan penyajian data-data akademik yang dibutuhkan siswa, orang tua dan pengguna yang membutuhkan data sistem informasi. Sistem informasi ini dibangun untuk mengelolah dan menyajikan data-data akademik dengan mudah. Untuk mendukung hal ini maka digunakan teknologi pemrograman dan database sehingga media penyimpanan yang diyakini sampai saat ini masih sangat berguna dan membantu dalam menklasifikasikan data dan informasi[1].

Teknologi informasi merupakan dua hal yang tidak dapat dipisahkan saat ini, hal ini terlihat dari proses untuk mendapatkan informasi yang dapat diperoleh dengan cepat, tepat, dan akurat dengan didukung oleh kemajuan teknologi yang semakin canggih. Politeknik Harapan Bersama Tegal merupakan salah satu lembaga pendidikan yang memiliki sistem komplit dalam pengolahan datanya, yang mengharuskan semua data terolah dengan baik, tersimpan dengan rapih dan mudah ditelusuri. Tujuan penelitian ini adalah mengembangkan sistem informasi akademik pada politeknik Harapan Bersama Tegal dengan menggunakan Unified Modeling Language (UML) model sebagai pengembangan model yang dibuat. Hasil akhir penelitin ini adalah sistem informasi akademik berbasis web yang dapat memberikan optimalisasi pelayanan informasi kartu rencana Studi dan hasil nilai mahasisiwa Politeknik Harapan Bersama Tegal[2].

Kegiatan akademik merupakan proses dimana dilakukannya kegiatan Pendidikan yang pada aktivitasnya memerlukan informasi yang cepat. Akan tetapi dalam faktanya tidak sedikit kendala yang terjadi. Hal ini karena sering terjadi penumpukan data siswa dan mengakibatkan sulitnya pencarian data siswa apabila sewaktu-waktu data itu diperlukan, dibutuhkan waktu yang cukup lama dalam membuat laporan data siswa, pencatatan nilai akademik siswa kedalam buku nilai akademik siswa serta kedalam raport dan juga membuat laporan nilai akademik siswa yang harus diserahkan kepada kepala sekolah, melalui penelitian ini diharapkan dapat membangun sebuah sistem informasi akademik berbasis komputer yang dapat meminimalisasikan kekurangan yang terjadi sehingga dapat memenuhi kebutuhan informasi bagi para guru, siswa hingga masyarakat luas. Sistem informasi akademik yang dirancang pada penelitian ini menerapkan model Rapid Aplication
Development (RAD). Dengan model tahapan dalam rancang bangun sistem lebih dipersingkat sehingga menghasilkan sistem informasi yang baik[3]

Sistem informasi yang berjalan di Pondok Pesantren Salafiyah Al-Baqiyatussa'diyyah Tembilahan yang dalam pengolahan data akademiknya masih menggunakan sistem komputerisasi sederhana. Walaupun sudah di dukung dengan komputer tetapi hanya memanfaatkan office standar (Micrososft Office Excel dan Word) sehingga memungkinkan banyak sekali kesalahan dalam pengolahan data akademik. Sehingga menyebabkan pelayanan akademik yang diberikan oleh Pondok Pesantren Salafiyah Al-Baqiyatussa'diyyah Tembilahan menjadi kurang efisien, serta mengakibatkan kesulitan dalam pencarian data dan menyita waktu relatif lama dalam pembuatan laporan. Untuk membantu dalam menyelesaikan masalah tersebut perlu adanya suatu sistem informasi akademik yang baru agar setiap pekerjaan yang menyangkut pengolahan data dapat dikurangi tingkat kesalahannya serta dapat memberikan pelayanan yang memuaskan terhadap para pengguna sistem. Dalam perancangan sistem informasi akademik ini digambarkan ke dalam bentuk diagram Unified Modelling Language (UML)[4].

Perancangan sistem informasi akademik ini bertujuan untuk mempermudah siswa, guru dan pihak Madrasah Aliyah Al-Mansyuriyah Kanza yang sebelumnya mengetahui informasi yang cukup lama, disini saya mempermudah siswa, guru dan pihak Madrasah Aliyah Al- Mansyuriyah Kanza dengan sistem informasi akademik secara online, sehingga dapat lebih efisien dan efektif. Penelitian ini bertujuan membangun sebuah sistem informasi akademik berbasis web. Sistem perancangan dalam pembuatan website akademik pada Madrasah Aliyah Al-Mansyuriyah Kanza ini, dikembangkan dengan menggunakan beberapa software yakni Adobe Dreamweaver CS6, Xampp yang merupakan gabungan dari Apache Web Server, PHP dan MySQL[5].

Perkembangan teknologi komputer sekarang ini dengan kecepatan prosesnya telah memungkinkan pengembangan sistem informasi berbasis komputer. Penelitian ini membahas tentang pembuatan Web disalah satu sekolah menengah atas, karena melihat kualitas pengolahan data yang masih manual yaitu masih menggunakan kertas dan pulpen. Dengan menggunakan metodologi Waterfall, perancangan sistem informasi akademik berbasis web ini dapat meningkatkan kualitas pengolahan data akademik di sekolah tersebut. Dengan menggunakan PHP dan MySQL aplikasi ini dapat dirancang dengan mudah. Dengan adanya sistem informasi ini, membantu mempermudah pengolahan data akademik sekolah dan lebih maksimal dan praktis karena dapat di akses dari mana saja sekaligus menjaga data tetap aman 
yang sebelumnya semua dilakukan secara manual dan data mudah hilang[6].

Berhasilnya tata kelola organisasi saat ini sangat bergantung pada sejauh mana tata kelola dari Teknologi Informasi (TI) yang dilakukan. Penerapan TI ini akan berjalan dengan baik apabila ditunjang dengan suatu tata kelola TI yang baik pula. Pelayanan dalam bidang akademik adalah salah satu aktivitas utama perguruan tinggi yang berfungsi sebagai penyelenggara pendidikan. Dengan bertambahnya jumlah mahasiswa dan program studi, Universitas Muhammadiyah Purwokerto (UMP) harus meningkatkan layanan TI yang digunakan, dalam hal ini adalah layanan sistem informasi akademik. Proses pengelolaan permasalahan pada sistem informasi akademik merupakan hal penting karena proses tersebut berkaitan dengan penyediaan layanan terhadap seluruh civitas akademika[7].

SMA Negeri 9 Padang merupakan salah satu lembaga pendidikan, yang membutuhkan perancangan perangkat lunak dalam mengelola dan menjalankan segala aktifitas sekolah, salah satunya adalah Sistem Informasi Akademik (SIA). Saat ini SIA di SMA Negeri 9 Padang belum terintegrasi dengan baik, sehingga masih memiliki banyak kekurangan dalam memenuhi kebutuhan sekolah atau instansi tersebut, khususnya untuk menangani masalah akademik. Oleh karena itu perlu di implementasikan Sistem Informasi Akademik yang dapat mengatasi berbagai kekurangan tadi. Hasil penelitian ini menunjukkan bahwa perangkat lunak SIA Sekolah yang dipilih dan diterapkan yaitu aplikasi JIBAS, yang dapat mengatasi permasalahan pada SMA Negeri 9 Padang[8].

\section{Metode Penelitian}

Metode penelitian yang digunakan dalam penelitian ini adalah metode System Development Life Cycle (SDLC) dengan model Waterfall disebut model sekuensial linier (sequential liniear) atau alur hidup klasik (classic life cycle). Model air terjun menyediakan pendekatan alur hidup perangkat lunak secara sekuensial atau terurut dimulai dari analisis, desain, pengkodean, pengujian, dan tahap pendukung (Support).

Berikut ini akan dijelaskan tahapan model perancangan perangkat lunak mengunakan model waterfall :

A. system information engineering

merupakan bagian penting dari sebuah sistem yang besar, maka pekerjaan awal dimulai dengan menentukan kebutuhan-kebutuhan dari semua elemen yang diperlukan sistem dan mengalokasikannya kedalam pembentukkan perangkat lunak (software).

\section{B. Analisis (Analysis)}

Merupakan tahap dimana sistem engineering menganalisis sifat dari program-program yang akan dibangun, serta hal-hal yang diperlukan dalam pembangunan perangkat lunak (software).

\section{Perancangan (Desain)}

Merupakan tahap dimana langkah proses yang terfokus pada program-program struktur data, teknik software, prosedur detail dan penggolongannya serta menterjemahkan dari data yang dianalisa kedalam bentuk gambaran yang mudah dimengerti oleh pemakai (user).

\section{Pengkodean (coding)}

Merupakan tahap penterjemahan dari hasil perancangan bentuk yang maksimal yang dapat dibaca. Perancangan dilakukan dengan cara yang mendetail walaupun pengkodean dapat menyelesaikan secara mekanikal.

\section{E. Pengujian (Implementation)}

Merupakan tahap pengujian hasil rancangan (uji coba perangkat lunak), serta pengecekan untuk menentukan kesalahan-kesalahan dan menghasilkan output yang sebenarnya sesuai dengan permintaan.

\section{F. Pemeliharaan (Maintenance)}

Merupakan tahap dimana suatu perangkat lunak (Software) yang telah disampaikan kepada pemakai (user), dapat mengalami perubahan-perubahan atau penambahan sesuai dengan kesalahan yang ditemukan dann permintaan dari pemakai (user).

\section{Entitiy Relationship Diagram (ERD)}

Dalam rekayasa perangkat lunak, sebuah EntityRelationship Model (ERM) merupakan abstrak dan konseptual representasi data. Entity-Relationship adalah salah satu metode pemodelan basis data yang digunakan untuk menghasilkan skema konseptual untuk jenis/model data semantik sistem. Dimana sistem seringkali memiliki basis data relasional, dan ketentuannya bersifat top-down. Diagram untuk menggambarkan model Entitiy-Relationship ini disebut Entitiy-Relationship diagram, ER diagram, atau ERD. Ada sejumlah konvensi mengenai Notasi ERD. Notasi klasik sering digunakan untuk model konseptual. Berbagai notasi lain juga digunakan untuk menggambarkan secara logis dan fisik dari suatu basis data, salah satunya adalah IDEF1X [9].

Logical Record Stucture (LRS) adalah pemodelan basis data yang digunakan untuk mengimplementasikan rancangan ERD ke dalam basis data yang sesungguhnya.

\section{Unified Modelling Language}

Selama hampir sepuluh tahun, Unified Modeling Language (UML) telah menjadi standar industri untuk memvisualisasikan, menentukan, membangun, dan mendokumentasikan artefak dari sistem intensif perangkat lunak. Sebagai bahasa pemodelan standar de facto, UML memfasilitasi komunikasi dan mengurangi kebingungan di antara para pemangku kepentingan proyek. Standarisasi UML 2.0 baru-baru ini semakin memperluas cakupan dan kelayakan bahasa. Sifat ekspresifnya 
yang melekat memungkinkan pengguna untuk memodelkan segala sesuatu mulai dari sistem informasi perusahaan dan aplikasi berbasis web terdistribusi hingga sistem tertanam waktu nyata [10].

\section{Hasil dan Diskusi}

\section{A. Proses Bisnis Sistem}

Menjelaskan tentang bagaimana pihak atau elemen yang terkait di sekolah yang melakukan serangkaian aktivitas yang berhubungan dengan kegiatan akademik di SMK Bina Medika. Berikut penjelasannya: pertama- tama bagian kurikulum membuatkan jadwal mengajar guru dan jadwal pelajaran siswa dan kemudian menyerahkan kepada guru pengajar dan wali kelas untuk menyerahkan jadwal pelajaran kepada siswa. Seluruh siswa wajib mengikuti kegiatan belajar di kelas kemudian wali kelas merakap semua nilai siswa yang telah diterima dari guru data nilai tersebut kemudian dibuat laporan kedalam buku rapor. Kemudian diserahkan kepada siswa sebagai hasil dari rangkaian proses pembelajaran.

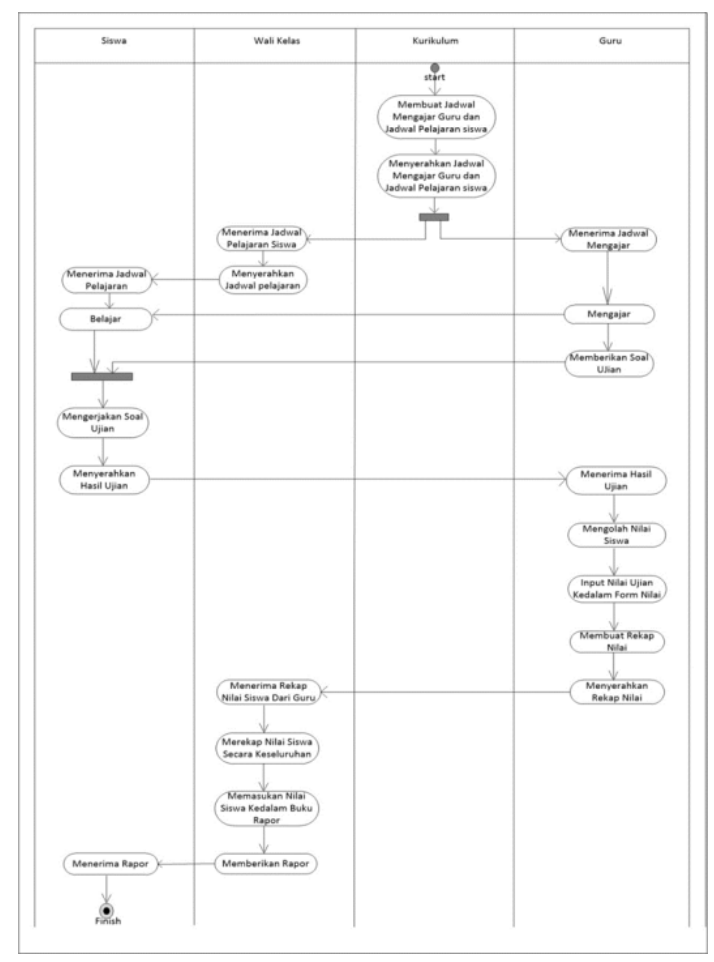

Gbr 1 Activity Diagram Proses Sistem Berjalan

\section{B. Entity Relationship Diagram (ERD)}

ERD dalam sistem informasi akademik berbasis web pada SMK Bina Medika Cilangkap sebagai berikut.

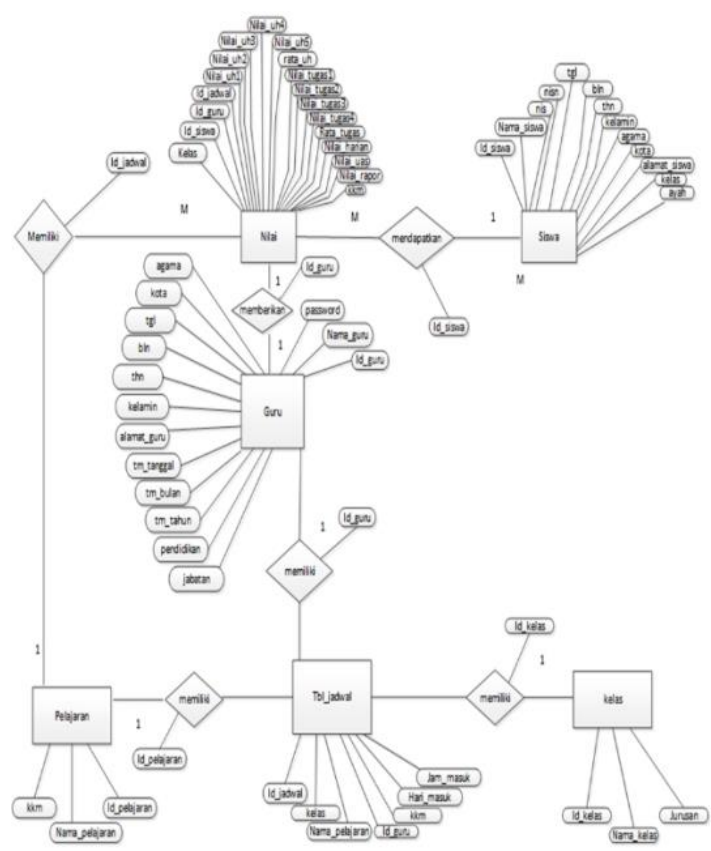

Gbr 2 ERD Sistem Informasi Akademik SMK Bina Medika

\section{Logical Record Structure (LRS)}

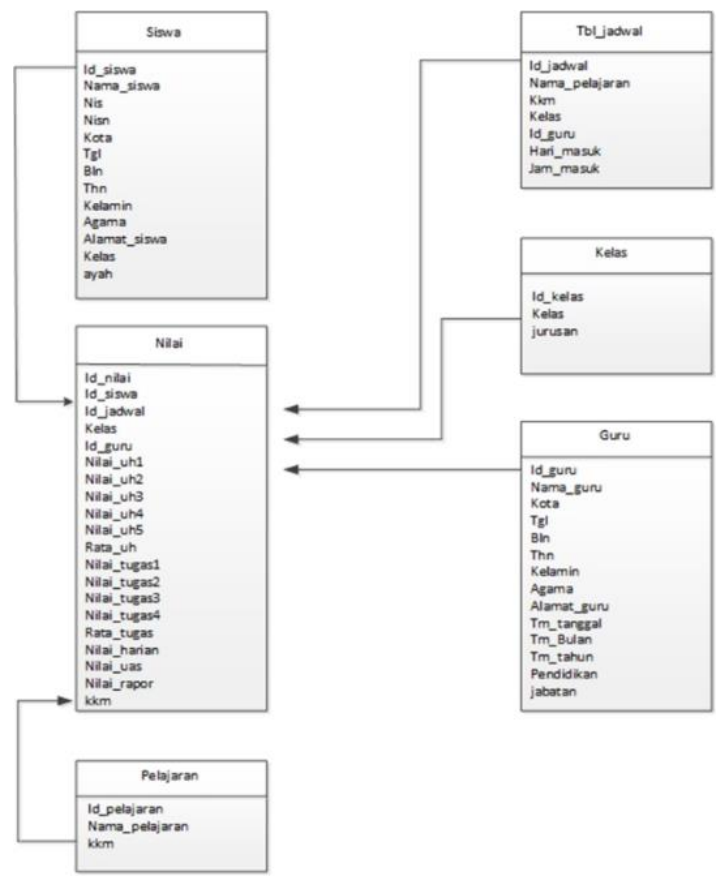


Gbr 3 LRS Sistem Informasi Akademik SMK Bina Medika

\section{Sequence Diagram}

1. Sequence Diagram Admin Mengelola User

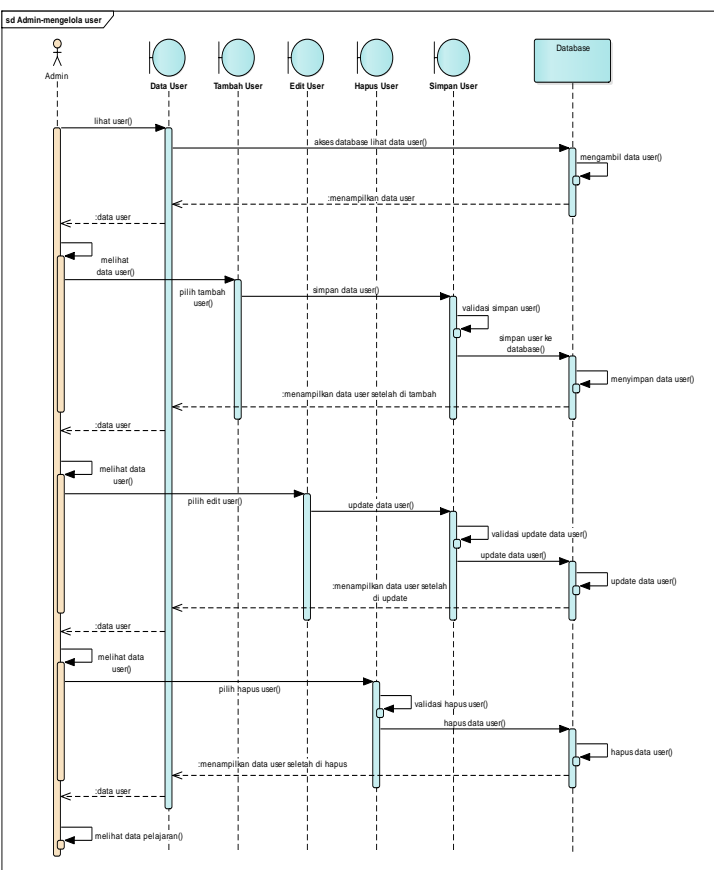

Gbr 4 Sequence Diagram Admin Mengelola User

2. Sequence Diagram Admin Mengelola Guru

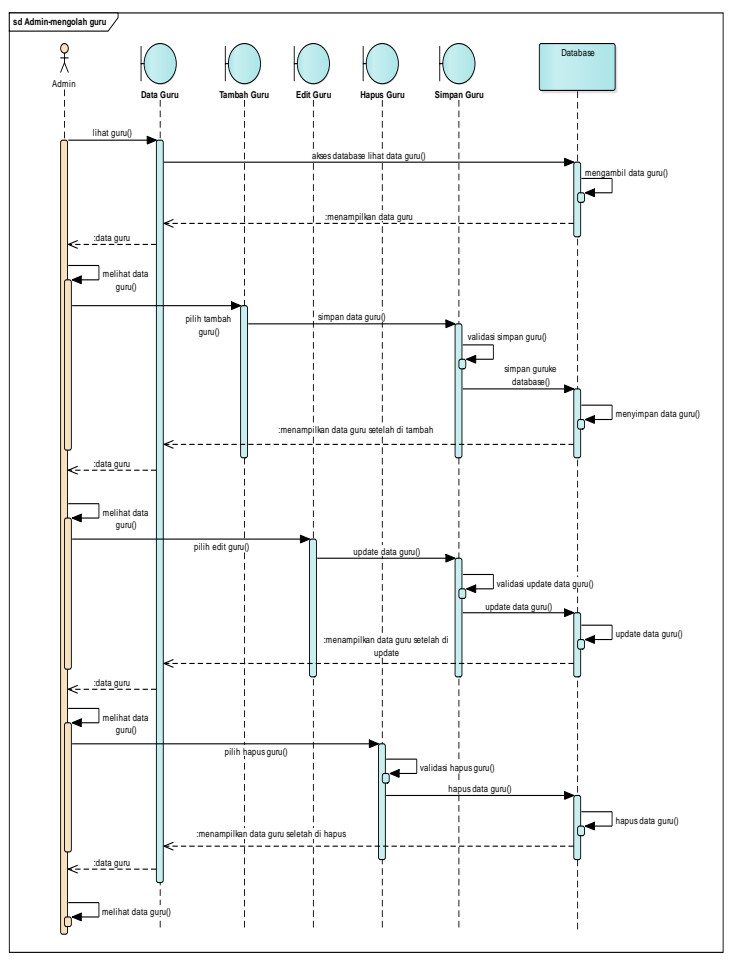

3. Sequence Diagram Admin Mengelola Siswa

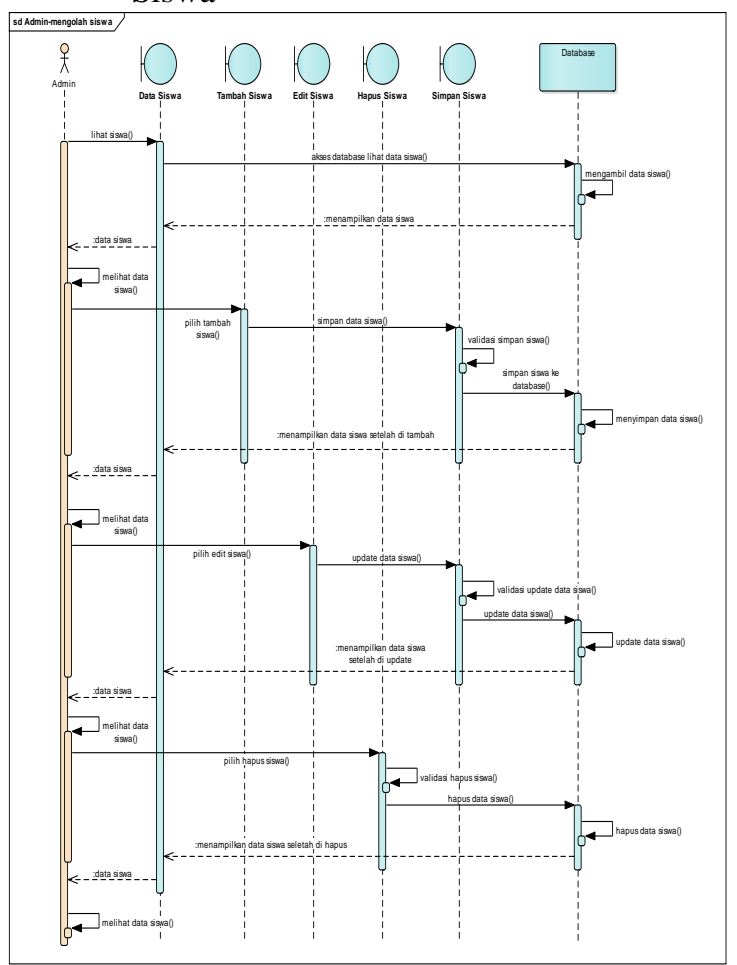

Gbr 6 Sequcence Diagram Admin Mengelola Siswa

\section{G. Component Diagram}

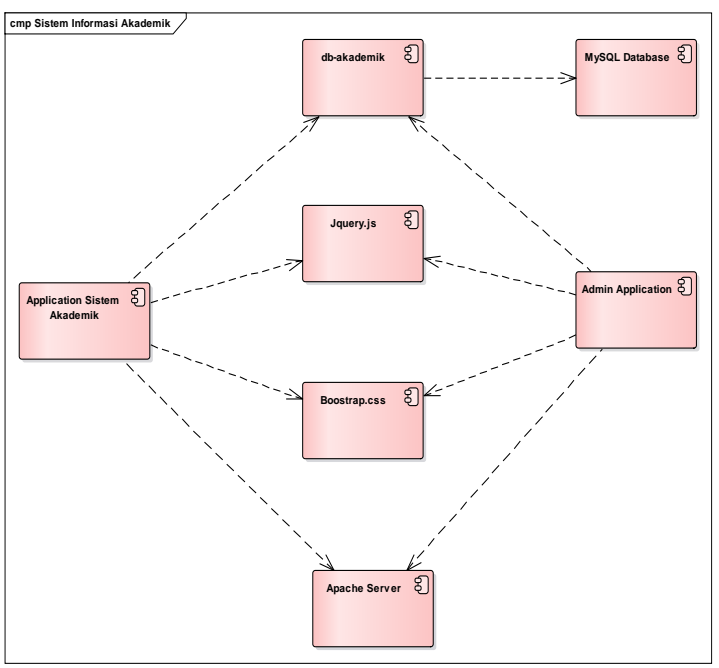

Gbr 7 Component Diagram Sistem Informasi Akademik

Gbr 5 Sequence Diagram Admin Mengelola Guru 


\section{H. Deployement Diagram}

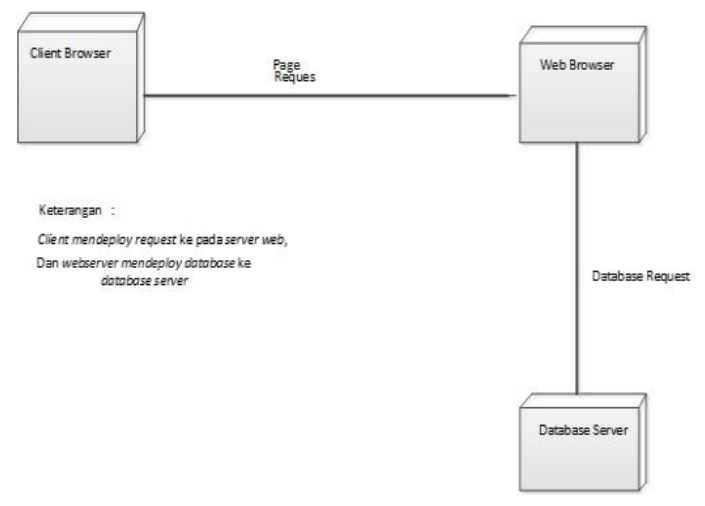

Gbr 8 Deployement Diagram Sistem Informasi Akademik

\section{User Interface}

Halaman Login

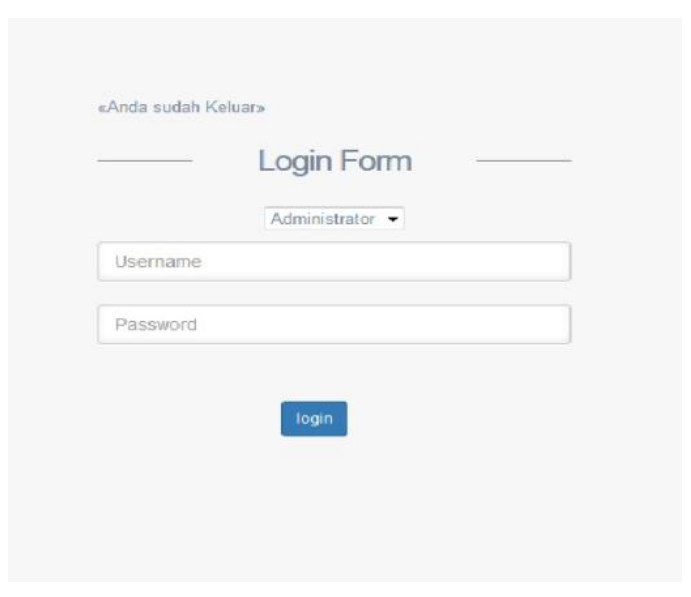

Gbr 9 Halaman Login

Form Input Data Siswa

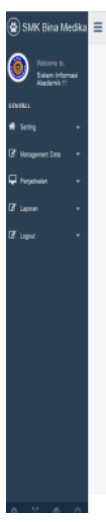

\section{Form Input Data Guru}

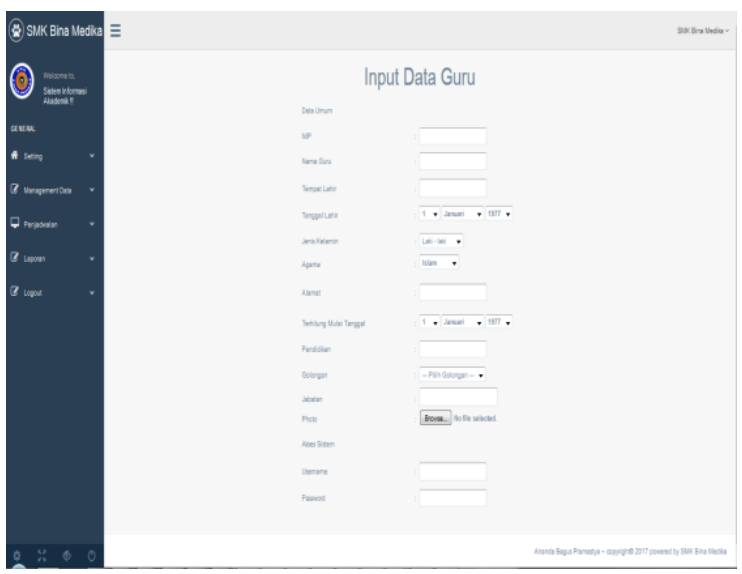

Gbr 11 Form Input Data Guru

Form Input Nilai

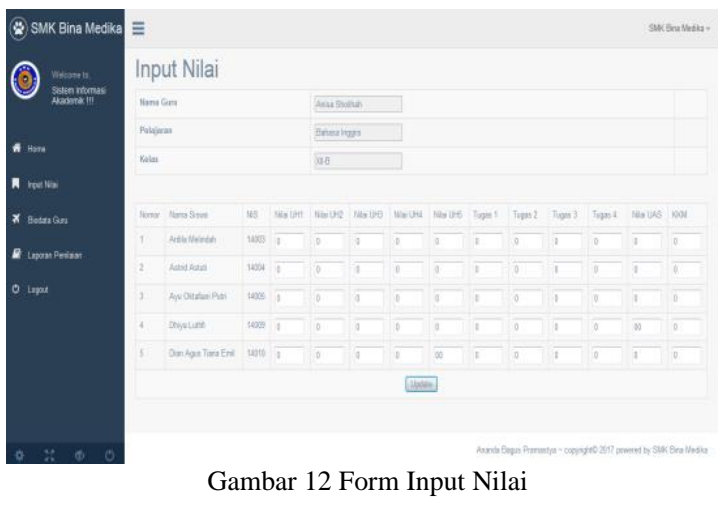

\section{Penutup}

Sistem informasi berbasis web dapat menyajikan infromasi akademik di SMK Bina Medika yang dapat mempermudah murid dan guru untuk melihat data-data akademik berupa data nilai, biodata guru maupun biodata siswa dan jadwal pelajaran siswa. Sistem informasi akademik ini lebih mudah melakukan input data guru maupun siswa, dan penyimpanan arsip data yang sudah di input tanpa khawatir arsip tersebut hilang atau rusak.

Untuk merancang sistem informasi yang baik diperlukan kerja sama yang baik antara pengembang dan pemakai, sehingga informasi tentang kebutuhan sistem dapat terpenuhi. pentingnya menjaga kerahasiaan password untuk menjaga keamanan data agar tidak sembarang orang mengakses data tersebut. Kemudian pihak sekolah dapat mengembangkan sistem informasi akademik yang lebih kompleks sehingga semua pihak termasuk orang tua murid dan calon siswa. 


\section{Referensi}

[1] I. G. Ngurah and A. Indrayasa, "Analisis Dan Perancangan Sistem Informasi Akademik Pada Sekolah Menengah Atas ( Sma ) Berbasis Web," pp. 6-8, 2015.

[2] M Teguh Prihandoyo, "Unified Modeling Language (UML) Model Untuk Pengembangan Sistem Informasi Akademik Berbasis Web," J. Inform. J. Pengemb. IT, vol. 3, no. 1, pp. 126-129, 2018.

[3] F. Agustini, "Penerapan Model Rapid Aplication Development Dalam Sistem Informasi Akademik," vol. 2, no. 2, pp. 159170, 2018.

Sistem Informasi,"

Jurnalnasional.Ump.Ac.Id, vol. V, no. November, pp. 103-113, 2017.

R. Akbar, T. Rahmawati, and . A., "Implementasi Sistem Informasi Akademik Menggunakan Aplikasi Jibas pada SMA Negeri 9 Padang," J. Nas. Teknol. dan Sist. Inf., vol. 1, no. 1, pp. 36-41, 2015.

[9] E. Didik, "Entity Relationship Analysis," 2017. [Online].

Available: https://sis.binus.ac.id/2017/09/08/en tity-relationship-analysis/. [Accessed: 14-Oct-2019].

[10] G. BOOCH, UNIFIED MODELING LANGUAGE USER GUIDE. ADDISON-WESLEY, 2017.

[4] A. Burrahman, "MEMBANGUN SISTEM INFORMASI AKADEMIK BERBASIS WEB PADA PONDOK PESANTREN SALAFIYAH AL-

BAQIYATUSSA'DIYYAH TEMBILAHAN," SISTEMASI, vol. 6, no. 1, p. 33, May 2018.

[5] M. A. AS and N. A. Septiani, "PERANCANGAN SISTEM INFORMASI AKADEMIK MENGGUNAKAN METODE WATERFALL Studi Kasus: MADRASAHALIYAH ALMANSYURIYAH KANZA MEKARJAYA TANGERANG," $J$. Techno Nusa Mandiri, vol. 13, no. 2, pp. 165-172, Sep. 2016.

[6] R. T. Djaelangkara, R. Sengkey, and O. A. Lantang, "Perancangan Sistem Informasi Akademik Sekolah Berbasis Web Studi Kasus Sekolah Menengah Atas Kristen 1 Tomohon," J. Tek. Elektro dan Komput., vol. 4, no. 3, pp. 86-94, May 2015.

[7] L. Purwanto, T. D.-J. J. Informatika, and undefined 2018, "Pengukuran Tingkat Kematangan Tata Kelola Pengelolaan Permasalahan Sistem Informasi Menggunakan Kerangka Kerja COBIT 4.1 (Studi Kasus: 